\title{
Discussion on possibility of community-based waste management views from citizen environmental consciousness: A case of rural area in Karang Joang Village, Balikpapan Indonesia
}

\author{
Indriyani Rachman ${ }^{a}$, Toru Matsumoto ${ }^{b *}$ \\ aDoctoral Course, Graduate School of Environmental Eng., University of Kitakyushu, 1-1, Hibikino, Wakamatsu-ku, \\ Kitakyushu-shi 808-0135, Japan.

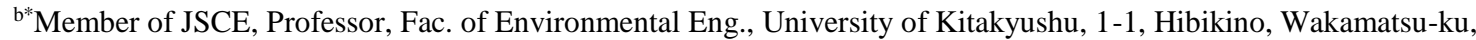 \\ Kitakyushu-shi 808-0135, Japan. \\ *Corresponding E-mail address: matsumoto-t@ kitakyu-u.ac.jp
}

\author{
ART ICLE INFO \\ Article history: \\ Received 1 April 2016 \\ Received in revised form 2 April 2016 \\ Accepted 30 June 2016
}

Keywords:

Solid waste management

Awareness

Environmental education

\begin{abstract}
A B S T R A C T
The habit of Karang Joang people is throwing garbage, inherited from generation to generation. Most of treating's their garbage are by burning it in the yard, throwing into the garden or the river. The transportation to take garbage that isn't intensive by city officers and the lack of knowledge in managing the garbage greatly affects the pollution condition of the air, soil and water in the village. This research focuses on the patterns of society in treating organic waste and inorganic. Environmental conditions in the village to make some attention from the city government Balikpapan. Because the village is located in a protected forest manggar should be kept clean. We distributed questionnaires to 500 housewives that are living in 12 areas near the river. We interviewed one of the small shop and 5 housewives about what they buy and how dispose of waste in one day. Approximately 5-7 sachet plastics and around 200-300 grams of organic garbage. And approximately one drum of water is used for one family. Six months after distributing questionnaires and analyzing, we held a workshop with theme on the importance of ecofriendly living, composting of organic garbage, and counseling about bank of garbage program for 32 leaders in the village. Then we try to find solutions about how to build the consciousness and management in solid waste. In this study, some possible solutions have been presented by transfer environmental technologies
\end{abstract}

(C)2017

\section{INTRODUCTION}

Indonesia have UU No 18/2008 regarding about managing and arranging the paradigm changes from waste disposal to waste recycling released by State Minister of Environment, Municipal Solid Waste must be managed by reduction and treatment. The reductions comprise of minimalizing the solid waste, recycling and reuse. While the treatments consist of waste separation, waste recollecting or re-transporting and waste processing. Most of people in Indonesia, however, manage the solid waste only by collecting, transporting, and disposing to the landfills without optimizing reduce, reuse, and recycle program. (3R).Indonesia, as a developing country, has lots of environmental issues to cope with. The increases of population, economy and people activities unquestionably give rise to the volume of waste. If it does not take care properly, the waste problem will never end. Although people do not yet support the program fully, at least, there has been a program which encourages people to reduce and also to manage the waste 
properly. There has been emerging bank of waste program currently in Indonesia. This program will potentially reduce the waste disposal and extend the life of landfills.

The research is conducted in KarangJoang Village Balikpapan Indonesia. It is located in the northernmost of Balikpapan City and has protected forests with reservoir dam as drinking water supply for people in Balikpapan. Total population of KarangJoang Village is around 1000 people divided into 31 neighborhood associations.

It has the area asthe extent of one-third of Balikpapan consisting of a half of protect forests, dam and village. Most of people in the village are vegetable farmer and merchant. There are main problems of this research is about People pattern in treating organic and inorganic waste.

KarangJoang people has been doing an inherited custom which has been passed on for a long time ago, that is throwing the organic and nonorganic waste. The patterns which had been always done are to burn the garbage in the yard or backyard, to throw the garbage away to the river for those whose houses near the river and also for other people living in some other neighborhood associations.

In some KarangJoang neighbourhood, the waste which is not transported has become common problem. As a result, it already piles up in the temporary rubbish container. There are some reasons why the waste is not transported even though people have paid retribution for it. As in interview result, the most reason found is the truck to transport the waste rarely comes to the location. Accordingly, most people prefer disposing the waste to their garden or burning it in their backyard. In fact, this results air and soil pollution. This research is intended to give solution what people must do relating to their surrounding waste. If this bad pattern is still going on, the pollution will even get worse.. Had the government facilities still have not been able to transport the garbage, when the community has already paid the waste retribution. Then the community should take action on their own and take the initiative to conduct the management of garbage.

This study is aimed at finding out a model of a problem solving for a case telling that many places or villages that are far from the centre of the city have a problem on transporting the garbage, including the problems and obstacles in managing the household waste. Dealing with this, there are some designs in managing the garbage to be discussed in order to find out the most proper way in overcoming this kind of problem.

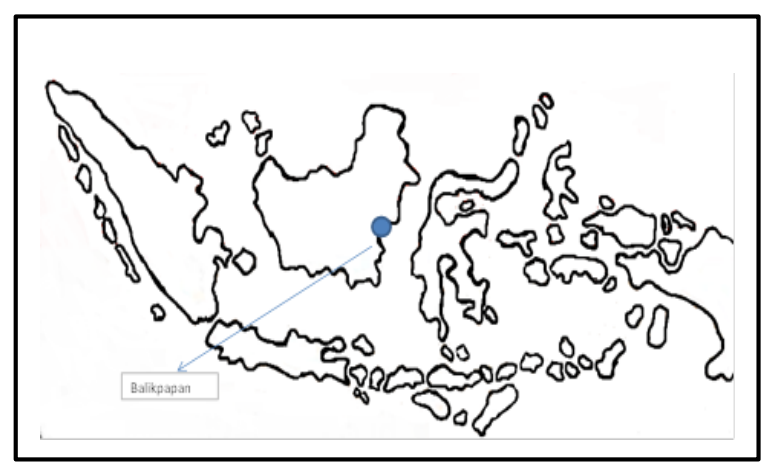

Figure 1. Location of research

\section{METHODOLOGY}

This research use the qualitative and quantitative method. Questionnaire to the people coming into the area of research and interviews to some traders / shop and houses. The method used in this study are:

\subsection{Distribution of the questionnaire and interview}

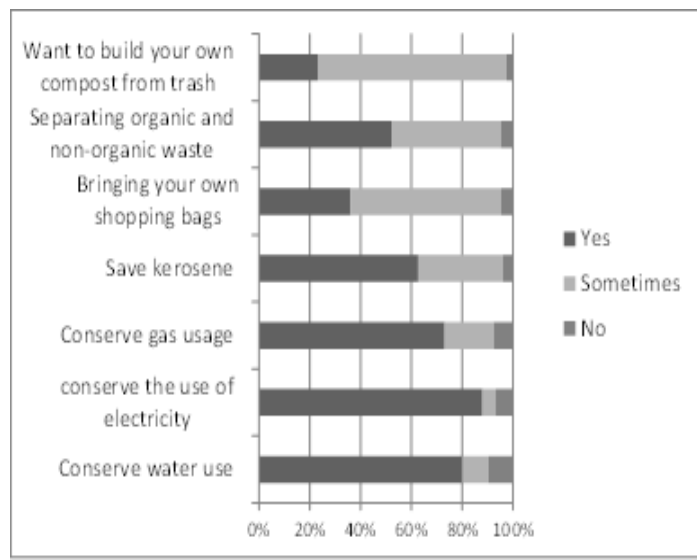

Figure.2 Eco-friendly lifestyle in current condition

We focused to the people lifestyle living near the dam. We gave questionnaire to the 500 families in 12 living area near the river. We conducted the interview to 5 housewives regarding to what they have bought and how much garbage or waste they produce every day. 
We also interviewed the owner of a small grocery store who sells his products for people in RT (neighborhood association) 12. From the interview result, it was obtained that one family produced around 5-7 plastics in sachets and 200 to 300 grams of organic waste in a day.

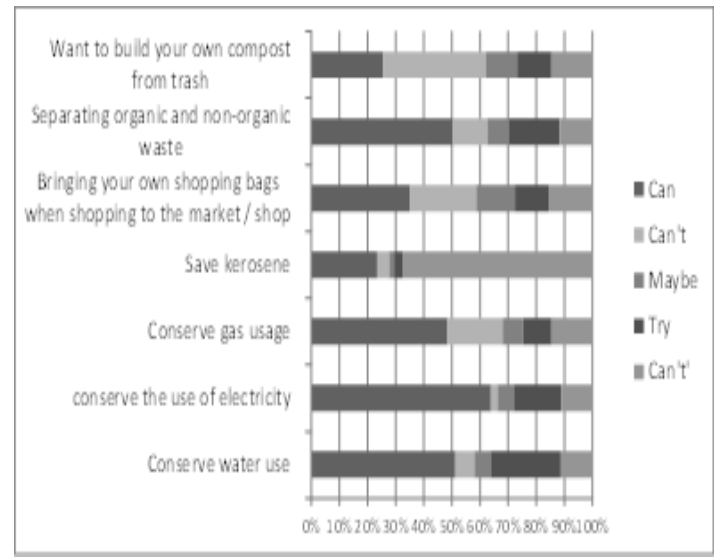

Figure. 3 Eco-friendly lifestyle in the future

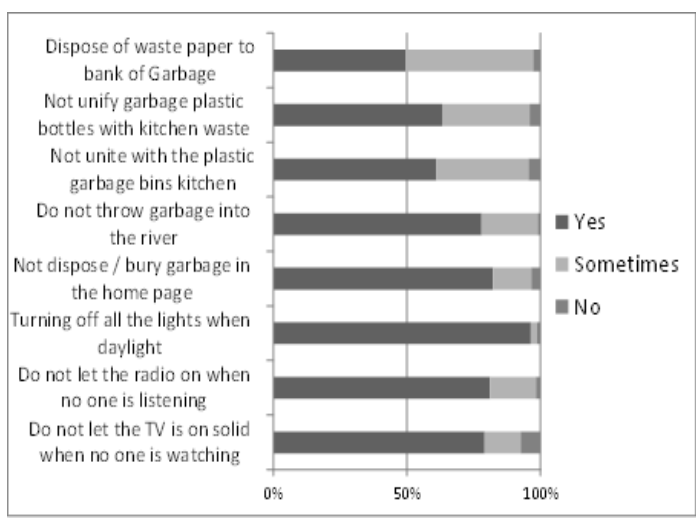

Figure.4 Eco-friendly lifestyle in current condition.

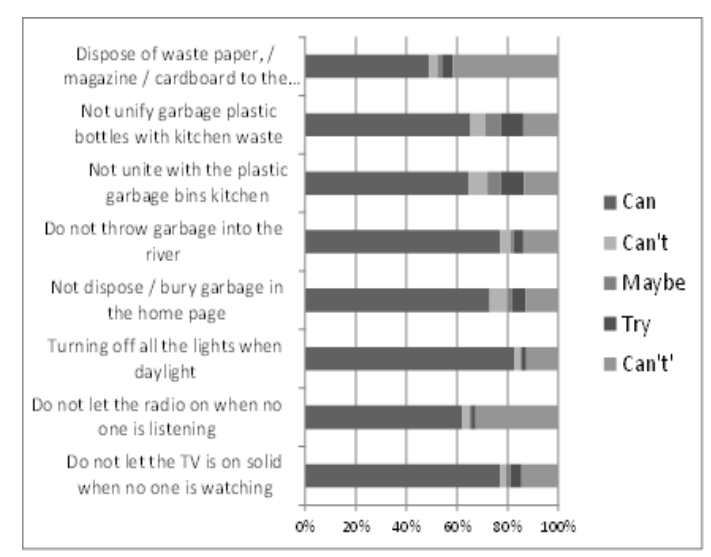

Figure. 5 Eco-friendly lifestyle in the future
Six months after getting the result of questionnaire and data analysis, we conducted a workshop for KarangJoang people. The topics were government policies about waste disposal management, introduction to Takakura compost production with biopori method, introduction to centralized waste disposal and material about the importance of eco-friendly living near houses and river.

Eco-friendly education is indeed necessary to change how people behave and think, particularly in buying the products so they will not produce much waste

\subsection{Swot analysis}

This type of analysis attempts to figure out all possibilities that exist in that village involving the strength, the weaknesses, the opportunities and the easiness. All those factors will be summarized and analyzed in order to find out the solution for this case.

\subsection{Discussion model}

Some problem solving models in the management of garbage that will be provided are adapted to the condition of the results of SWOT analysis in KarangJoang village. Therefore, the appropriate management model will be found

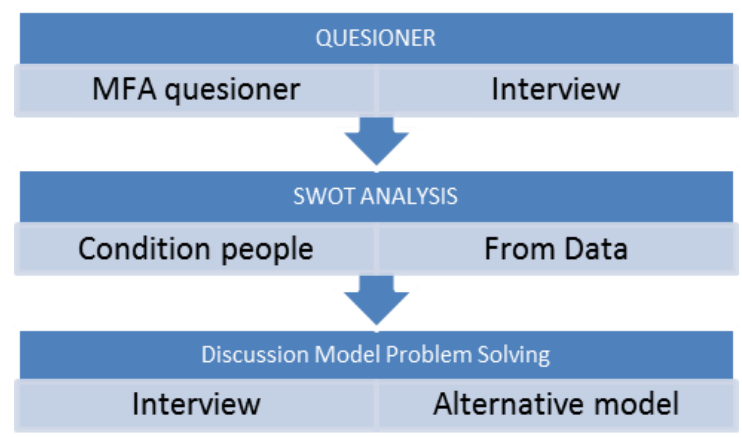

\section{RESULTS AND DISCUSSION}

\subsection{Solid waste management pattern}

The results of the questionnaire were distributed, it was found the following results:

Making compost training can be done through PKK (Family Welfare Movement) and religious group in mosque. The questions about compost (in Fig. 2 and 3) asked, we can compare as follows: from question about 
garbage now performs live with the pattern of environmentally friendly, in the future they can be in-depth chart. They can maintain the habit. While those who answered No and sometimes, they are answering divided over maybe, and try. It means there is a possibility they attempt to do so. According to the questionnaire result about current people lifestyle and compared to the pattern of life to come, it seems that KarangJoang people has spirit to fix their life pattern to be eco-friendly. Although the use of eco-bag is not the common thing now, they can probably use it for the next time. It is also for producing compost. By looking at the rise of 25 $\%$ from the questionnaire answer According to the results of the opinion poll, the public is not so much coral Joang energy sources. Average vehicle they own a motorcycle. There is still people who use firewood for cooking.

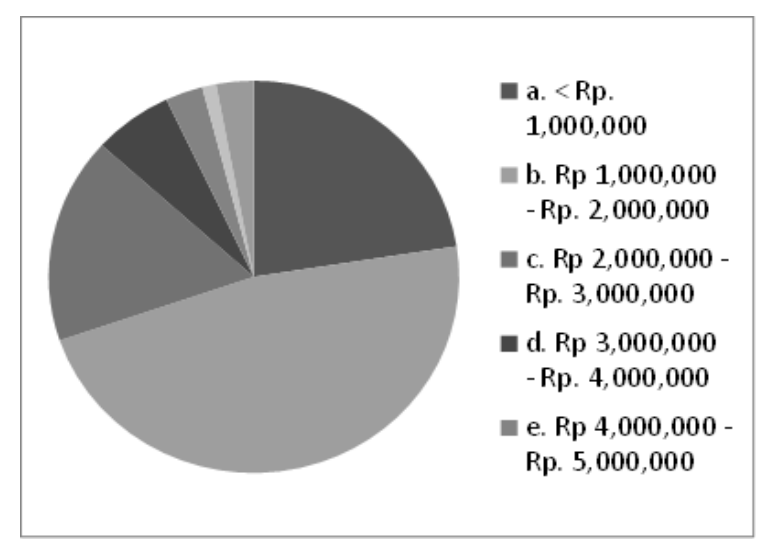

Figure.7 Income per-month

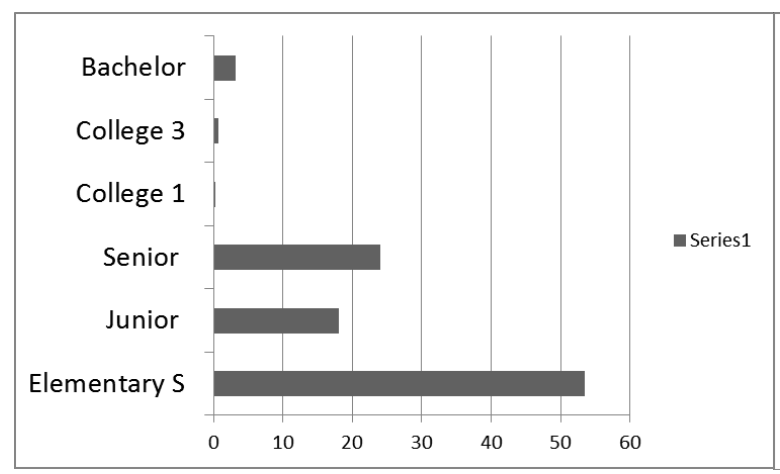

Figure. 8 Education Level

In the next graph (Fig. 7 and 8), the same as in the previous graph, those who answered Yes, the future still be able to live with a friendly environment. On the question of throwing garbage in the river $75 \%$ do not throw garbage into the river. The restsometimes. But in future, become maybe can not throw garbage into the river.

Expected by society no longer dispose of waste both kitchen waste and organic organi into rivers and creeks. Garbage settles on the edge of the river that causes the river becomes unhealthy. Riverbanks filled with rubbish bins plastic sachet of food and beverages. Plastic bags commonly used by people often settles in the river so much garbage piled up. One of the causes of flooding are making large amounts of waste water does not flow. One of the habits of the population Karang Joang, when taking out the trash glass bottles. They bury it in the backyard. This habit lasted continuously. Surely when glass bottles and other glass brought to the bank of Garbage would be more useful.

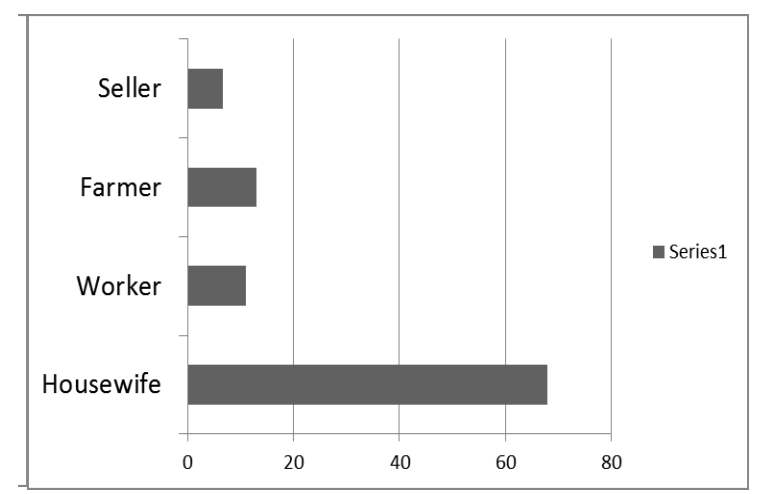

Figure.9 Average housewife job

Income chart (with the low of family income, the bank waste will at least help the society economy)Almost 50\% people of Karang Joang have income between Rp. 1.000 .000 to Rp. 2.000.000. While according to People's Regional Representative Council of Balikpapan in Economy, the minimum wage relative is $\begin{array}{lll}\text { ranged between } \mathrm{Rp} & 2.100 .000\end{array}$ includedincentives(http://kaltim.tribunnews.com /2013/11/15/umk-balikpapan-dinilai-masihjauh-dari-harapan).

If we see on the chart, the family income average of Karang Joang people can be categorized middle to lower income. Therefore, if Karang Joang people can join to the Bank of Waste Member, they will have additional income for their daily needs. Besides, if we see from the amount of organic waste produced by a household, it can potentially enable to make compost. Based on the questionnaire result, the 
organic waste produced by a household is about 250 gram. This potential waste is more than enough to produce household compost by using Takakura method. Moreover, in this village, people has a house with large and huge yard in average. This enables for them to start planting flowers to sell.

For example, from the results of questionnaires distributed, that $90 \%$ of moms from 12 RT targeted research, they are housewife with education level as in Figure 8 and the average job is a housewife in Figure 9.

\subsection{Swot analysis}

Six months later after the questionnaire was given, we held a workshop divided into two sessions concerning about compost production by using Takakura method and biopori method in the first session. In the second session, we gave material about introduction to the bank of waste. The workshop was started from 8 to 12 AM. It was attended by 38 representatives consisted of wife of head and financial manager of neighborhood association.

After a year and a half of training, we interviewed urban village head of Karang Joang about the people development in environmental program. According to urban village head, there are three banks of garbage in that village, those are on 16 and 17 Besides, the villagers has already started making compost and preserve the environment. The changes of the village are also supported by Water Supply Company of Balikpapan and also Legal Assistance Institution of Balikpapan.

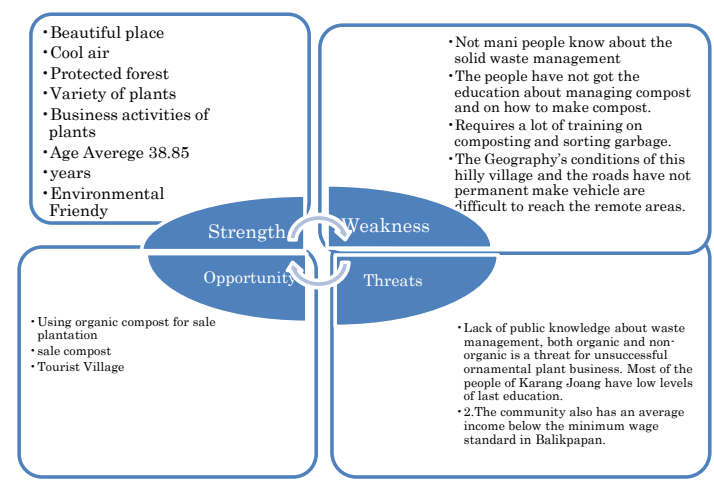

Figure. 10 SWOT Analysis

The current waste problem can be handled with managing the waste from the smallest one and producing the compost for organic waste. If these programs can be kept on going, the waste problem in Karang Joang will reduce.

The bank of waste has actually come up in Balikpapan city since 2011. However, its achievement is still relative low. It is different from the composting program. Most of schools have its compost processing for school garden needs. This program is done by the teachers along with the students who are engaged in loving environmental movement. Nevertheless, these two programs are not yet administered in KarangJoang Village. In fact, the programs can be beneficial to change garbage into economic materials if we see from the total population and the amount of waste that the people produce. From the analysis of the questionnaire showed that $48.30 \%$ of people did separating trash between organic and non-organic. And 44.4\% didn't. and $7.3 \%$ did it sometimes. But if we look at the table, whether people make compost from organic waste, then we can see the results: only $33.3 \%$ of the people make organic waste into compost. But if the whole society amounted to $48.30 \%$, make compost from organic waste that they have already separated, then the amount of waste that burned will be reduced.

Results of a cross table between the level of education with junk dispose pattern is obtained as follows. About six months after the questionnaires were given, we arranged a oneday workshop for the people in KarangJoang . This workshop invited representation from each of the neighbourhood association (RT) as many as 3 people. It was divided into two sections. The first section was a training about the compost production using Taka Kura and bio Pori method. In the other section, we introduced them what a bank of garbage is. On the explanation, we told them about the benefit of bank of garbage, the way of its working, and how to sell it. We also told them the role of people in the management of it. The workshop was started from 8 a.m. to 12 p.m. This event was attended by 38 representations which consist of the head of finance's wife and the manager of finance from the environment association. After a year and a half of training, we interviewed the village chief on the development of society in KarangJoang in environmental programs. 


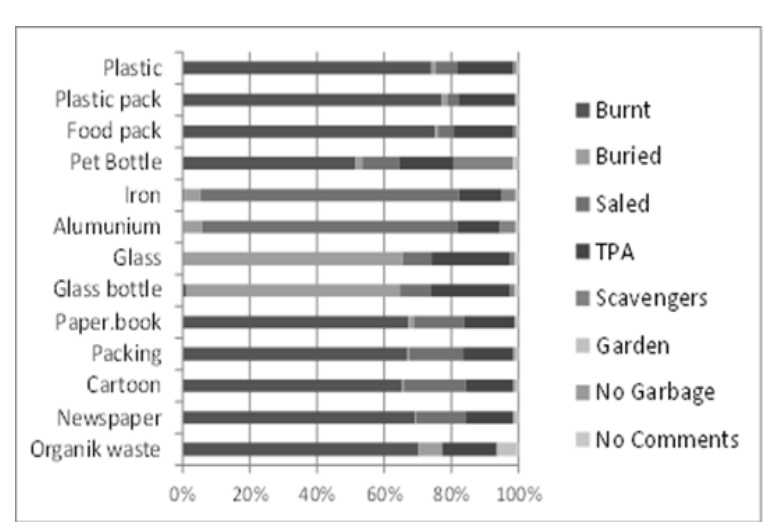

Figure.11 Pattern of dispose of solid waste

According to the village chief, there are three banks of garbage in the village; they are in RT 16 and RT17. In addition, the village has started to make compost and preserve the environment. The changing in the village is also supported by the Drinking Water Company (PDAM) Balikpapan and also the Legal Aid Society of Balikpapan. Current waste problem can be dealt with managing from the smallest waste and produce compost for organic waste. If the program can keep on going, then, the problem of garbage in KarangJoang will be solved.

Bank of garbage already existed in the Balikpapan city since 2011. However, performance is still relatively low. This is different from compost program. Most schools have already had a program to manage the compost for the school garden needs. The program is conducted by the teachers along with the students involved in taking care of the environmental movement.

\subsection{Discussion}

There are some solutions that can be applied to solve the problem by considering some requirements and conditions that must be fulfilled. As a step to solve this problem, the government has to make a program of garbage bank aiming to make the society sell the nonorganic garbage to the garbage bank. Additionally, the government is also suggested to manage the organic garbage by spreading the way to make the compost using takakura method. Therefore, the people will understand and be able to compose it by themselves.

\section{Solid waste management pattern}

Management based is one of policy implementation of managing waste enforced by government. Through this management based, it is expected that the waste will finally reduce.

The people are expected to participate in managing the compost and to reduce plastic bag use. Based on the questionnaire result, it is discovered that KarangJoang people have this following waste disposal pattern: for more than $50 \%$ respondents answered that they burnt plastic waste, plastic packaging, plastic wrap, paper, carton, newspaper, and organic waste. While for iron and aluminium waste, they prefer selling to junkman in the village, but if there is not much amount of them, they let them in garbage container. Besides, there is unofficial dustman in the village called scavenger. $\mathrm{He}$ usually goes around the village to take waste of cardboard, paper, iron and aluminium. Meanwhile, KarangJoang people custom which is inherited hereditarily concerning about waste is to bury garbage glass and glass bottles. We can see that people are used to burning the organic waste in their backyard or some other people did to their garden without any treatment. But it can potentially be useful if we can change this waste organic into compost that they can use to fertilize their vegetable. Moreover, most of them are vegetable farmer.

The Ministry of Environment regulation is focused on empowering people in managing the waste. According to Aras Mezzo theory (Suharto, 2005:66), this empowerment is conducted by using group as intervening media. Educating, training, and group dynamic are some ways to use in increasing people awareness, knowledge, skill and attitude which can be empowered to possess the ability to solve problems they face.

Some cities in Indonesia have started to implement some managing waste program which is community-based. This program is aimed at reducing the waste in those cities. The problem to deal with is about the low of local government budget to manage the waste. It particularly happens in some areas that are difficult to reach by vehicle. To implement the waste managing program fully, people participation is really required, for example, Surabaya, as the second largest city after 
Jakarta, possesses waste managing program administered by local government, nongovernmental organization, and also cooperating with Kitakyushu city. The first step to take is to make waste management model which is developed by a group of people through producing compost program. After getting some instructions and trainings, people no longer throw the garbage to the street nor the river. As the result, the environment has become not only green but also clean. This method can also be applied in KarangJoang village.

Nowadays, KarangJoang village has become tourist village for Balikpapan citizens. This is because of the existence of Dam Manggar and the position of village which is located in the hills. The fresh air throughout the year has made this village as a favourite destination to visit. The potential as tourist village can be more improved only if the people willingly preserve and more exploit the village advantages.

If the people on village are given some training to make compost and to plant flower, there will be possibility for the village to have one special product on that village. Becoming tourist village of flowers can truly increase people income. Therefore, the only solution over the problem is about how the local government can empower KarangJoang people to be productive in managing and preserving the nature. By giving the training about houseplants or decorated plants, making the compost, and showing how to keep the environment will make people aware of the environment. Besides, most of women in KarangJoang village are housewives. This could be advantageous simply because they can run a business by planting decorated flowers and it will give additional income for the family. This program will work only if the government can help financially by lending the first capital with low interest. Beside money needed to start the business, training to plan and to preserve the flowers is also very important.

Another potential that can be exploited from KarangJoang Village is to make the product which originally comes from the village. It can begin with planting one unique vegetable from the village considering the garbage bank in the village, so that all people can sell non-organic garbage into the garbage village has fertile soil and fresh air.

However, these two programs have not been granted in KarangJoang village. Currently, Balikpapan city is trying to resolve the problem of waste that disposed to landfill. The transporting level is still very low. Especially KarangJoang village is a bit away from affordability. The difficulty of garbage trucks to go into KarangJoang makes accumulating garbage bins on the curb, at some points of landfills. There is no separation of landfill, the people still used the traditional techniques.

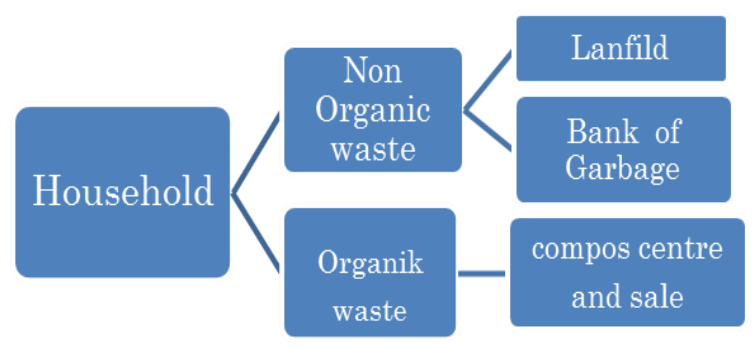

Figure. 12 Alternative 1 for waste management flow

One alternative for waste management is to begin at the household level. How households can sort their own garbage. For wet waste from the kitchen can be used as compost or use biopori hole. While non-organic parts that can be sold we can sell to the bank or disposed of to landfill for waste that does not have the selling price. One of the alternatives, which is proposed, is the separation of landfill space. Where TPA is divided into two parts, one for organic waste / household waste and one for wet and non-organic waste. This is one way to lengthen the life of the landfill.

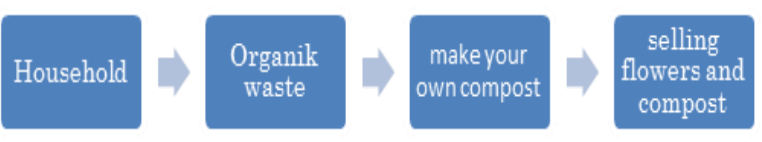

Fig. 13 Alternative 3 waste management flow

The second alternative is created compost house in the village of KarangJoang which is managed by a village or sanitary service. There are some things that can be done with regards to solving this problem. With some terms and conditions that must be met. Stages that must be done is that the government create a program of-

bank. As for the organic waste, the government suggested to disseminate to the public how to 
compost with takakura method, so that people can understand and do it their selves. One of the first steps is no less important, governments and communities to make composting home. In which the compost house will accommodate all residents and processed organic waste at composting home. The government also makes a product called one product one village for KarangJoang village. This program is used to do farming or sell decorative plants in the yard. Of course, this program needs counselling and learning of how to plant flowers in order to make the society run this program. One of places in Indonesia that has conducted the program one product one village is Cihideng village in Lembang, Bandung in which almost all society has the same job; selling plants and vegetables. Additionally, the result of questionnaires in KarangJoang village can be a tourism village selling decorative plants.

If we see the SWOT, we will know that there are three models that can be alternatives in solving this problem.

1. As the first alternative, every household separates garbage into two big parts; nonorganic and organic waste. The non-organic waste is divided into two parts; the organic waste that can be sold to the garbage bank and the one which can not be given to the garbage bank. The home composting (rumahkompos) has to own a vehicle that is used to trasnport the household garbage. The garbage in the home composting will be processed and sold freely or bought by the government for the needs of the city park.

\section{REFERENCES}

The Environment Ministry of the Republic ofIndonesia. (2014). The Waste Management Policy.

The environment ministry of the Republic of Indonesia. (2012). The Bank of Garbage Indonesia.

Toshizo Maeda. (2009). Reducing Waste Through the Promotion of Composting and Active Involvement of Various Stakeholder

Replicating Surabaya's Solid Waste Management Model, Police Brief.
2. The second alternative, every house composes the compost and sends it to the centralagent in that village functioning to sell it. Additionally, the compost can be also distributed to the seller of or sold to the public

3. Every house composes the compost that is used to fulfill the needs of the household. As an instance, a family uses the yard to sell flowers and sell the compost.

\section{CONCLUSION}

To keep the environmentally friendly habits, today it takes a lot of training or counselling from the government, especially relevant institutions that responsible with counselling. As it is done in the city of Kitakyushu. Initially people don't understand what to do. Kitakyushu City makes leaflets, training, and referrals for people when faced with the latest litter laws. Dissemination to the public require quite a long time. Basically KarangJoang village has the potential to become a thriving village through garbage management. With the number of inhabitants and the amount of waste that is issued allowing the village to be independent in managing its waste. Participation of the community and government assistance to manage waste would be very beneficial for the survival of the village. Instilling public awareness for environmentally friendly living is a shared task between the city government, local government and the community.

Ministry of Environment of the Republic of Indonesia. 2014. Waste Management Policy in the Application of Alternative Renewable Energy RourceTechnologies. Deputy assistant waste management.

Confintea. (1997). Adult Environmental Education Awareness and Environmental Action". Hamburg.

JICA. (2014). Strategy Paper on Solid Waste Management.

Ayu Fitriana. (2013). Perilaku Ibu Rumah Tangga dalam Pengelolaan Sampah di Desa Bluru Kidul Rw 11 kecamatan Sidoarjo. 
Surahma Asti Mulyasari. (2014). Kebijakan Pemerintah dalam Pengelolaan Sampah domestik, Government policy in Domestic Waste management, Kesmas.

http://www.indonesia.go.id/id/index.php?option $=$ com_content $\&$ task $=$ view $\& \mathrm{id}=4488 \&$ Item i $d=701$

http://www.dpr.go.id/artikel/terkini/artikel.php? aid $=2824$
Yuzarian Faulizar Pohan. (2012). PengelolaanSampahPerumahanKawasanPe desaanBerdasarkanKarakteristikTimbulan Sampah di Kabupaten Gresik, Jurnal Teknik Pomits, 1, 2301-9271.

José Canga-Rodríguez. (2006). Modern Wastewater Treatment Solutions in a Stateof-the-Art Pharmaceutical Production Environment. Germany. 